MARKETING IN ADVERSITY 
By the same author

MARKETING: AN INTRODUCTORY TEXT

MARKETING NEW INDUSTRIAL PRODUCTS

PRODUCT POLICY AND MANAGEMENT

(with R. McTavish) 


\section{MARKETING IN ADVERSITY}

\section{Edited by}

Michael J. Baker

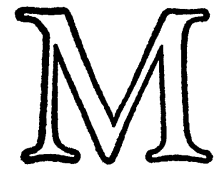


Selection, editorial matter and Chapter 1 (C) Michael J. Baker 1976 Chapter 2 (C) Kenneth Simmonds 1976 Chapters 3-7 inclusive (C) The Macmillan Press Ltd 1976 Softcover reprint of the hardcover 1st edition 1976

All rights reserved. No part of this publication may be reproduced or transmitted, in any form or by any means, without permission

First published 1976 by THE MACMILLAN PRESS LTD

London and Basingstoke Associated companies in New York Dublin Melbourne Johannesburg and Madras

SBN 333196619

ISBN 978-1-349-02958-7

ISBN 978-1-349-02956-3 (eBook) DOI 10.1007/978-1-349-02956-3

This book is sold subject to the standard conditions of the Net Book Agreement 


\section{Contents}

Figures vii

Preface ix

Biographical notes on the contributors xiii

1 Marketing and the Future 1

Short-term survival

Marketing and zero growth

Zero growth rejected

An end and $a$ beginning

2 Marketing Action for Changing Times

Changed demand patterns from changing incomes

Changing the data collection

Changing capital goods market

Changing actions with changing costs

Identifying the best actions

Adversity is change is opportunity

3 The Consumer, The Market Place and the Marketing Mix $\quad 26$

The market background

The consumer response to inflation: buying behaviour

The consumer in the market: conclusions

The marketing mix: tactics for survival

Prices: problems and limitations

Advertising

Packaging

Other areas

Conclusions

4 Marketing Research

Introduction

Nature of marketing research

Value of marketing research information

Execution

Interpretation and usefulness of findings

Economic and social changes

Summary 
5 Marketing Control and Pricing in Inflation

Introduction

Inflation and stagnation

Marketing priorities

Marketing planning in inflation

Planning and the marketing budget

Conclusion

6 Marketing in Adversity: the International Dimension

The cause and extent of the zero growth condition

The national and international company

Exports and imports

Conclusion

7 Marketing: Not for Profit?

Introduction

The marketing concept defined

The marketing concept destroyed?

The responsibilities of marketing managers

Museum marketing

Road safety

Political candidate marketing

Political market research

Family planning

Police departments

Churches

University marketing

Social marketing

Conclusions 


\section{Figures}

5.1 Distinguishing characteristics of buying situations

5.2 Relationship between inflation, price changes and profit contribution

5.3 The market planning framework

5.4 Lorenz diagram for the product mix

7.1 A comprehensive political marketing map 


\section{Preface}

Traditionally, Marketing has been associated with conditions of economic growth, demand stimulation and increased personal consumption. Now, however, the current world-wide recession has resulted in extensive questioning not simply of the desirability of a consumption orientated society but of the possibility of sustaining it - at least in its present form - given wider acceptance of the world's finite resource base. In turn, the relevance of Marketing as an activity has been challenged on two fronts - short and long term. In the short term, managers are seeking advice as to the appropriate tactics to be adopted to help survive these unfavourable conditions; while for the long term they are seeking help in forecasting the shape of things to come and assistance in formulating appropriate strategies to cope with the predicted future state.

As a consequence, managers are being called upon to deal with not only the usual concomitants of a down-turn in the business cycle but also with a fundamental examination of the relationship between buyer and seller both nationally (consumerism and consumer protection) and internationally (commodity agreements, etc.).

In the course of any examination of the buyer-seller relationship it soon becomes apparent that there has been a marked reaction against 'marketing' from a number of directions and for a variety of reasons. In managerial circles the unbridled enthusiasm of the 1960s, which promoted marketing as the panacea for all corporate ills, has been replaced by a more sceptical, more objective, and dare one say, healthier appreciation of the marketing function. Similarly, the consumerist voices in the wilderness of the past decade are now coming into their own as the energy crisis underlines the penalties of excessive consumption and lends weight to forecasts of supply deficiencies in the foreseeable future. Government has welcomed this surge of consumer interest for it provides a welcome diversion from inquiry into its own deficiencies and shortcomings. Thus, while it extols the virtues of choice, which is the natural consequence of free market competition, it extends the dead hand of public ownership which promises to reduce drastically such choice. More, consumerism like cleanliness and godliness is 'a good thing' and so nonpolitical and not to be debated in an unseemly manner.

It is inherent in human nature to emphasise the exception to the rule, to pick out the oddity or dwell on the bad rather than the good 
news. Accordingly, marketers should not be surprised at the sudden change in their status from favoured son to whipping boy because of perceived shortcomings in their craft. None the less, marketers would be less than human if they did not react to their changed status by asking themselves whether there is merit in the criticisms directed against them and, if so, what may be done to alleviate the sources of such criticism. The contributions to this book were conceived much in this spirit.

A fundamental theme of this book is a reassertion of the belief that a marketing orientation offers the best solution to both the short-term adverse effects of a severe recession as well as to the longer-term problems facing a growing population with an apparently finite resource base. In essence the authors take the view that much criticism of marketing is both unfounded and unjustified, and stems from a misconception of the essential transactional philosophy implicit in the marketing concept. Thus, we would hold that the first principle of marketing is that our acknowledged scarce resources should be allocated in accordance with consumer preferences as expressed by them in their expenditure. In other words, marketing starts and ends with the consumer, and the basic objective is to establish and maintain a mutually satisfying relationship.

The book itself consists of a series of invited contributions from a panel of distinguished authors and opens with a general view of the case against marketing. In essence Michael Baker argues that while the exigencies of the present world-wide recession are bound to assume priority over the more distant projections of zero or even negative growth, both are inextricably linked and so need to be considered in parallel. At the same time it is equally true that failure to survive the short term eliminates consideration of the longer-term possibilities and demands immediate and specific diagnosis and treatment. After exploring both short- and long-term scenarios it is accepted that the western industrialised economies may well be undergoing a major change into a 'post industrial society', but it is argued that the discipline of marketing, with its emphasis upon research, forecasting and planning, is probably best equipped to enable this transformation to take place.

In Chapters 2 and 3 a distinguished academic (Professor Kenneth Simmonds) and an eminent practitioner (Dr. John Treasure) take a look at the short-term implications of an adverse economic climate. While both agree that we must adopt a positive approach and see if we cannot turn potential threats into marketing opportunities, there are some interesting differences of opinion as to the precise interpretation to be made of apparent changes in consumer behaviour. While Simmonds takes a broad look at the situation, Treasure develops his analysis in greater detail and concludes by reviewing the 
role of the various marketing mix elements in developing an appropriate strategy.

In Chapter 4, John Bound takes his cue from the plea for more and better research as a basis for informed decision making and discusses the way in which marketing research may contribute to both the direction and control of the organisation's activities - present and future. In a condensed, and often cryptic manner, Bound surveys many of the problems facing executives who are uncertain as to the contribution research may make in helping them solve their decision problems and offers much practical advice on these issues. $\mathrm{He}$ also underlines the points made by John Treasure that superficial changes in purchasing behaviour are often indicative of deep rooted social change of a wide ranging and fundamental character.

Peter Doyle is concerned primarily with the short to medium-term situation and offers much pragmatic and management orientated advice which highlights the need for planning and control in a depressed market situation. As he comments, 'Inflation and economic stagnation have significant effects on the decision-making processes of buyers and consequently upon the marketing orientation of companies. Marketing needs to give much greater emphasis to profit and cash flow, and rather less emphasis to gains in sales volume.' His prescription - a comprehensive profit-centred market planning and budgeting system - is discussed with considerable force and clarity.

By contrast, Chapter 6 by James Livingstone is concerned more with the long term and the strategic/top management implications of adverse economic conditions which he argues are merely a continuation of a long established trend. However, in examining the international dimension, Livingstone comes to the conclusion that our political decline as a world power may well enhance our options even if the adverse trends continue. These options are discussed in some detail and lead to the inescapable conclusion that increased prosperity is dependent upon an improvement in our international trade that will be best achieved through the adoption of appropriate marketing strategies.

In the final chapter Michael Thomas extends the debate in order to address the issue of the transferability of the marketing concept and marketing techniques into other areas and especially those where pecuniary profit is not a major objective. First, however, he takes a look at the social responsibility of marketing against the backcloth of criticism levied at it by environmentalists, consumerists and advocates of zero growth, and expresses the opinion that much of the criticism is directed at the search for profit rather than at marketing per se. Thus, if we consider non-profit organisations, it becomes clear that marketing is amoral rather than immoral, for its technology is available to all. In the final analysis, however, Thomas 
points out that we are faced with a conundrum, namely, 'Is marketing defined by the subject matter it deals with or by the technology with which the subject is handled?'

If we are correct in our assessment of the likely readership of this volume, such a conundrum is both a fitting start and conclusion to this book, for the authors accept that in answering certain problems we continually create new problems that demand a solution. This is the challenge of management and we will have achieved our purpose if our efforts have provided both answers to questions and questions to be answered.

Michael J. Baker

University of Strathclyde

December 1975 


\section{Biographical Notes}

Professor Michael J. Baker has been Professor and Head of the Department of Marketing at the University of Strathclyde since 1971. From 1968 to 1971 he was a Foundation for Management Education Fellow at the Harvard Business School and also held joint research appointments at both the Business School and the Marketing Science Institute. On graduation and completion of his National Service he joined Richard Thomas \& Baldwins Ltd, as a management trainee. During his six years with them he served in a number of different selling and commercial appointments before leaving to take up a lectureship in marketing at the Medway College of Technology and, subsequently, at the Hull Colleges of Commerce and Technology.

In addition to advising a number of companies on matters of corporate and marketing strategy, Professor Baker is Managing Director of a consultancy firm which has been retained by a wide spectrum of clients and President of the Marketing Education Group of the UK. $\mathrm{He}$ is the author of Marketing (now in its second edition and the most widely recommended British text) and Marketing New Industrial Products and also editor of the forthcoming Macmillan Series in Marketing Management as well as many articles and papers on various aspects of marketing.

JoHN A. Bound has recently made the transition from marketing research practice in industry to an academic appointment at Strathclyde. From research at Southampton he moved to the Central Statistical Office and worked on official statistics and their publication. He then originated the marketing research function with Quaker Oats Ltd, and in the course of nearly twenty years saw the problems and applications of research in a wide variety of marketing situations both in the UK and overseas. He is a Fellow of the Institute of Statisticians and Book Review Editor of the Journal of the Market Research Society.

Professor Peter Doyle is Professor of Marketing at the University of Bradford Management Centre. His research interests are in marketing strategy, market research methods and advertising. He is the author of Inflation and Analytical Marketing Management and of numerous papers in academic journals. Before joining the Uni- 
versity of Bradford he taught marketing at the London Graduate School of Business Studies. He has worked on the planning side of Unilever Ltd and been employed as a marketing consultant to a range of companies and public bodies.

James M. Livingstone is Reader in International Business in the Marketing Department of the University of Strathclyde. In the field of economics his initial specialisation was in international economics and his primary research interests were in the field of international finance. A growing conviction that conventional international trade and finance theory did not adequately explain prevailing developments in the growth of new industrial and trading patterns led him to concentrate on the rapidly developing field of study of international business and the transnational corporation. During 1971-2 Livingstone was on secondment to HM Treasury as a Senior Economic Adviser. Outside the immediate field of international business he has been engaged in a number of economic and social surveys, particularly in new towns, as well as in various market research and consultancy projects. He has written extensively on economic, management and marketing issues and is the author of Britain in the World Economy and The British Economy in Theory and Practice.

Professor Kenneth Simmonds is Professor of Marketing and International Business at the London Graduate School of Business Studies, where he is chairman of the marketing subject area and London Executive Programme. For the 1974-5 academic year he was Ford Foundation Visiting Professor of International Business at the Graduate School of Business, University of Chicago, followed by a term in New Zealand as Drapers' Company Professor at the University of Auckland. He has previously held positions in the graduate business schools of Harvard, Indiana and Manchester. His first full-time industrial job was in New Zealand and he subsequently worked in business in the USA, Britain and on the Continent. He has acted as a consultant in developing corporate strategies for several of the UK's largest corporations and has run advanced management programmes and seminars for many international firms. He has been directly involved in management in Britain as Director and permanent marketing adviser to a number of British corporations, public and private. In addition to books in the marketing field, Professor Simmonds co-authored the Irwin text International Business and Multinational Enterprises with Professor Stefan H. Robock of Columbia University Business School. He has written many articles, particularly in the fields of international business strategy, decision making models, and industrial and capital goods marketing. 
Michael J. Thomas is Senior Lecturer and Head of the Department of Marketing at the University of Lancaster, an appointment he has held since 1971. After national service and university, he spent three years as Market Research Manager with the Metal Box Company. Then he returned to the United States to take up a research appointment at Syracuse University and, successively, appointments as Instructor and Assistant Professor. During this period he was responsible for both the Management Development and Executive Development programmes. He has been employed as a consultant with a broad spectrum of organisations in both the United States and United Kingdom and is the Managing Director of a small publishing business which he set up to produce and market limited editions of prints.

Mr. Thomas played a central role in the foundation of the National Marketing Education Board in 1975.

Mr. Thomas is the author of International Marketing and Modern Marketing Management (with R. J. Lawrence) and has contributed articles and papers to a wide variety of publications and conferences in both the USA and Europe.

Dr. John Treasure has been Chairman of J. Walter Thompson and BMRB and Senior Vice President and Director of the J. Walter Thompson Company in New York since 1967. He joined the company in $195^{2}$ as Research Adviser in BMRB, becoming Managing Director of BMRB in 1957 . He is the first non-resident of the USA to be elected to the Board of the American company and since 1973 he has been Vice Chairman.

Before joining the company he lectured on economics at universities in the UK and the United States including Harvard and Columbia. 